\title{
KOMITMEN INDONESIA DALAM PELINDUNGAN WARISAN BUDAYA BAWAH AIR DI PERAIRAN INDONESIA
}

\author{
A.D. Agung Sulistyo \\ Fakultas Hukum Universitas Indonesia \\ email: ad.agung@ui.ac.id \\ Arie Afriansyah \\ Fakultas Hukum Universitas Indonesia \\ email: arie.afriansyah@ui.ac.id
}

disampaikan 26/10/2020 - di-review 02/11/2020 - diterima 02/11/2021

DOI: $10.25123 /$ vej.v7i2.4339

\begin{abstract}
This article discusses the extent to which Indonesia provides legal protection to prehistoric and historical object, especially shipwrecks, found within its national waters. It is known that Indonesia has not decide to ratify the UNESCO 2001 Convention on the Protection of Underwater Cultural Heritage (UNESCO 2001 Convention). Legal audit performed to existing national rules and regulations reveals that, legally wise, Indonesia has shown its commitment to ensure that underwater cultural heritage within its maritime zones enjoy protection. In addition, it may be argued that therefore Indonesia is not in a position having to ratify the UNESCO 2001 Convention soon.
\end{abstract}

Keywords:

UNESCO 2001 Convention; underwater cultural heritage; protection of shipwreck

\begin{abstract}
Abstrak
Tulisan ini mengangkat masalah perlindungan hukum yang diberikan Indonesia melalui hukum nasional pada objek purbakala dan bersejarah, khususnya kapal karam, di perairan Indonesia. Sementara itu diketahui bahwa Indonesia sampai saat ini belum meratifikasi Konvensi UNESCO 2001 tentang Perlindungan Warisan Budaya Bawah Air (Konvensi UNESCO 2001). Penelusuran atas sumber-sumber hukum nasional berkaitan dengan hal ini menghasilkan simpulan bahwa aturan perundang-undangan nasional telah cukup menunjukkan adanya komitmen negara untuk melindungi warisan budaya bawah air dan selanjutnya Indonesia tidak perlu terburu-buru memutuskan untuk meratifikasi Konvensi UNESCO 2001.
\end{abstract}

Kata kunci:

Konvensi UNESCO 2001; warisan budaya bawah air; kapal karam

\section{Pendahuluan}

Wilayah Perairan Indonesia, yakni laut teritorial beserta perairan kepulauan dan perairan pedalaman merupakan wilayah laut Indonesia yang melekat kedaulatan Negara Kesatuan Republik Indonesia. ${ }^{1}$ Di wilayah laut yang

\footnotetext{
$1 \quad$ Undang-undang R.I., No. 32 Tahun 2014, Kelautan, L.N.R.I. Tahun 2014 No. 294, pasal 5 ayat

(2) dan 7 ayat (1).
} 
sangat luas itu bersemayam ratusan kapal karam asing beserta Benda Berharga Asal Muatan Kapal yang Tenggelam (BMKT) yang mengandung nilai sejarah, budaya dan ekonomi yang tinggi. Kementerian Kelautan dan Perikanan RI mengidentifikasi setidaknya terdapat 463 titik lokasi BMKT. ${ }^{2}$ Oleh Organisasi Pendidikan, Keilmuan, dan Kebudayaan Perserikatan Bangsa-Bangsa (United Nations Educational, Scientific and Cultural Organization/UNESCO), kapal karam beserta muatannya itu dikategorikan sebagai Warisan Budaya Bawah Air (Underwater Cultural Heritage/UCH). Nilainya yang luar biasa telah menarik minat banyak pihak atau kepentingan, baik Negara bagi kepentingan publik maupun swasta dalam tujuan komersial. Pengangkatan BMKT di wilayah Perairan Indonesia yang diklaim sebagai milik Negara asing adalah salah satu isu yang seringkali mencuat. ${ }^{3}$ Beberapa kasus penjarahan kapal karam asing pun telah berujung kecaman pada Indonesia. ${ }^{4}$ Kondisi ini telah memantik berbagai pendapat dan diskusi tentang komitmen Indonesia dalam melindungi warisan budaya bawah air, khususnya kapal karam asing yang tenggelam di wilayah kedaulatannya.

Semula, keberadaan peninggalan bawah laut dianggap tidak layak secara ekonomi. Minimnya kemampuan manusia dalam melakukan eksplorasi bawah laut menjadi penyebab utama arkeologi maritim hampir tidak pernah diperhatikan. Sebagian besar dari rezim hukum arkeologi maritim tersebut telah menjadi topik yang terabaikan. ${ }^{5}$ Hingga di tahun 1940 -an, kemunculan teknologi

2 Kementerian Kelautan dan Perikanan Republik Indonesia, FAQ Barang Muatan Kapal Tenggelam (BMKT) (Maret, 2018), https://kkp.go.id/artikel/2639-faq-barang-muatan-kapaltenggelam-bmkt, diakses 9 April 2020.

3 Maria Rita Hasugian, 24 Kapal Perang Asing Karam di Perairan Indonesia (Maret, 2019), Tempo.co, https://dunia.tempo.co/read/1181105/24-kapal-perang-asing-karam-di-perairanindonesia, diakses 18 April 2020; Natali Pearson, Finders not keepers (Maret, 2016), Inside Indonesia, https://www.insideindonesia.org/finders-not-keepers, diakses 10 November 2020; Linton Besser, "HMAS Perth: WWII warship grave stripped by salvagers," https://www.abc.net.au/news/2013-12-13/outrage-as-warship-grave-stripped-bysalvagers/5156320, diakses 17 April 2020.

4 Rio Apinino, Respons Prihatin AS \& 'Kutukan' Inggris Soal Aksi Penjarahan Kapal (Januari, 2018), Tirto.id, https://tirto.id/respons-prihatin-as-kutukan-inggris-soal-aksi-penjarahankapal-cDZd, diakses 6 Maret 2021.

5 Lowell Bautista, Ensuring the Preservation of Submerged Treasures for the Next Generation: The Protection of Underwater Cultural Heritage in International Law, prosiding LOSI Conference Papers "Securing the Ocean for the Next Generation" at Seoul, Korea, Mei, 2012, hlm., 4. 
selam yang dikenal dengan Self-contained Underwater Breathing Apparatus (SCUBA) telah mengubah secara drastis aktivitas manusia di bawah air. Aqua-Lung yang dikembangkan oleh Jacques-Yves Cousteau memungkinkan penyelam tinggal di bawah air lebih lama dari yang bisa dilakukan dengan satu tarikan nafas. ${ }^{6}$ SCUBA telah membuat peninggalan bawah laut yang semula tak terjamah semakin mudah ditemukan, dipulihkan, dan dipindahletakkan.

Teknologi ini dimanfaatkan oleh industri maritim komersial untuk melakukan eksplorasi, pemulihan, dan disposisi yang menguntungkan secara ekonomi. Pemanfaatannya terus berkembang hingga muncul tindakan recovery dan perdagangan UCH secara ilegal di tingkat nasional maupun internasional. Hingga akhirnya, perusakan dan penjarahan obyek arkeologi dan bersejarah itu tak terelakkan, merajalela, dan sulit diatasi.

Untuk itu, UNESCO menyusun dan mengembangkan prinsip-prinsip dan standar umum yang sesuai dengan hukum dan praktik internasional. Prinsip dan standar umum pelindungan UCH yang terangkum dalam The UNESCO 2001 Convention on the Protection of the Underwater Cultural Heritage (Konvensi UNESCO 2001) telah diterima pada sesi ke-31 Sidang Umum UNESCO pada tanggal 2 November 2001. Hingga 15 November 2019, Konvensi telah diterima atau diratifikasi oleh 63 negara. ${ }^{7}$ Berlaku efektif sejak 2 Januari 2009, yakni tiga bulan setelah tanggal penyimpanan instrumen kedua puluh Negara awal. Selanjutnya, sesuai Pasal 27, Konvensi ini mulai berlaku untuk masing-masing Negara pihak tiga bulan setelah tanggal di mana Negara itu menyimpan instrumennya. ${ }^{8}$

6 Ryan Patrick Jones, Jacques Cousteau and the History of Scuba Diving, Deepblu, https://www.deepblu.com/ post/81641b20107c11e7aa9ad181bc785596, diakses 17 April 2020; lihat juga National Association of Underwater Instructors, NAUI Leadership and Instruction, 3rd Ed., NAUI, United States of America, 2009.

7 UNESCO, Daftar Negara peratifikasi Konvensi UNESCO 2001 hingga 15 November 2019, http://www.unesco.org/eri/la/convention.asp?KO=13520\&language=E\&order=alpha, diakses 16 April, 2020.

8 UNESCO Convention on the Protection of Underwater Cultural Heritage, art. 27, November 2, 2001, UNESCO Doc 31C/Res 24; 41 ILM 372002. 
Konvensi ini merupakan instrumen internasional keempat yang menangani warisan budaya di bawah naungan UNESCO, ${ }^{9}$ dan yang pertama dalam hukum internasional yang secara khusus membahas tentang pelindungan UCH. Standar umum yang ditetapkan oleh Konvensi sebanding dengan standar warisan budaya lainnya yang selama ini telah ditetapkan oleh UNESCO dalam pengaturan mengenai warisan budaya di darat. ${ }^{10}$ Prioritas utamanya adalah memperkuat pelindungan UCH dari penjarahan dan perusakan yang dilakukan oleh para pemburu harta karun (treasure hunters) dan pihak yang terlibat dalam penyelamatan kapal karam beserta muatannya (salvors).

Karena pelindungan hukum atas benda purbakala dan bersejarah yang terletak di perairan internasional pada saat itu belum cukup diatur oleh hukum internasional yang ada, maka kehadirannya diharapkan dapat mengisi kekosongan hukum tersebut. Secara khusus Konvensi membahas celah dari rezim pelindungan yang sangat terbatas, kurang jelas, dan kontradiktif dari kerangka Hukum Laut PBB tahun 1982 (United Nations Convention on the Law of the Sea/UNCLOS 1982), ${ }^{11}$ yakni celah yurisdiksi di luar Zona Tambahan (Contiguous Zone) dan Landas Kontinen (Continental Shelf).

Konvensi UNESCO 2001 meyakini bahwa komitmen untuk meningkatkan efektivitas langkah-langkah di tingkat internasional membutuhkan kerja sama antara Negara, organisasi internasional, lembaga ilmiah, organisasi profesional, serta pihak berkepentingan lainnya. Instrumen ini mendorong Negara-negara pihak untuk melakukan kerja sama arkeologi bawah laut, transfer teknologi, dan berbagi informasi, ${ }^{12}$ dengan menggunakan standar etika dan ilmiah yang tinggi,

9 Tiga konvensi lainnya adalah: The 1954 Hague Convention on the Protection of Cultural Property in the Event of Armed Conflict (294 UNTS 215); the 1970 Convention on the Means of Prohibiting and Preventing the Illicit Import, Export and Transfer of Ownersihp of Cultural Property (10 ILM 289); dan the 1972 Convention Concerning the Protection of the World Cultural and Natural Heritage (1037 UNTS 151).

10 UNESCO, The UNESCO 2001 Convention on the Protection of the Underwater Cultural Heritage: Frequently Asked Questions, 2001, hlm., 4-6 dan 18.

11 Lowell Bautista, supra no. 5, hlm., 2.

12 lihat preambule Convention on the Protection of The Underwater Cultural Heritage, United Nations Educational, Scientific and Cultural Organization (UNESCO), Paris, 2 November 2001. 
serta kerja sama Negara yang efektif. ${ }^{13}$ Kepedulian internasional untuk menjaga obyek berharga tersebut mengarah pada pengakuan akan arti penting UCH sebagai bagian integral dari warisan budaya, sekaligus penghubung manusia dengan sejarahnya di masa lalu. Alasan tersebut turut mendorong sebuah kesadaran bahwa budaya, sejarah, dan arkeologi merupakan sumber daya yang terbatas dengan nilai yang sangat tinggi, melebihi sumber daya ekonomi.

Hingga saat ini, Indonesia belum meratifikasi Konvensi UNESCO 2001. Terdapat keengganan pula dari beberapa Negara untuk menerima Konvensi, terutama karena kepekaan politik atas pemberlakuan pembatasan pada kegiatan ekonomi penting di landas kontinen. ${ }^{14}$ Beberapa alasan lain pun muncul, yakni terkait perbedaan konsep pengelolaan, penafsiran hukum dan ilmiah, pemberlakuan prinsip-prinsip dalam kebiasaan internasional, serta pertimbangan manfaat yang dapat diperoleh. ${ }^{15}$ Alasan-alasan itu tidak bisa dilepaskan dari sejarah kelahiran Konvensi berupa proses negosiasi melelahkan selama satu dekade. Dalam proses tersebut, telah terbentuk garis pemisah baru antara komunitas arkeologi dan komunitas penyelamat harta karun (treasure salvage) dengan membawa nilai dan kepentingan masing-masing yang saling bertentangan. ${ }^{16}$

Makalah ini bermaksud menjawab pertanyaan tentang bagaimana kebijakan nasional Indonesia dalam melindungi warisan budaya bawah air, dan kaitannya dengan Konvensi UNESCO 2001? Mengingat hubungan yang tak terpisahkan antara Konvensi UNESCO 2001 dan UNCLOS 1982, maka dibutuhkan

13 Ulrike Guérin, What benefits can States derive from ratifying the UNESCO Convention on the Protection of the Underwater Cultural Heritage? (November, 2001), UNESCO, http://www.unesco.org/new/fileadmin/MULTIMEDIA/HQ/CLT/pdf/ Advantages\%202001\%20Convention.pdf, diakses 16 April, 2020.

14 Hans Peeters, Geoff Bailey, and Nena Galanidou, The Legal, Historical and Industrial Context of Underwater Heritage: Introduction, dalam Bailey G., Galanidou N., Peeters H., Jöns H., Mennenga M. (eds.) The Archaelogy of Europe's Drowned Landscapes, Coastal Research Library, vol 35, Springer, Cham. doi.org/10.1007/978-3-030-37367-2_25, 2020, hlm., 488.

15 Sorna Khakzad, Underwater Cultural Heritage Sites on the Way to World Heritage: To Ratify the 2001 Convention or not to Ratify? 2 (1) Journal of Anthropology and Archaeology, 2014, hlm., 11.

16 Anastasia Strati, The Protection of the Underwater Cultural Heritage: An Emerging Objective of the Contemporary Law of the Sea, Kluwer Law International, The Hague, 1995, hlm., 99; 117 121; Paul Fletcher-Tomenius and Craig Forrest, Historic Wreck in International Waters: Conflict or Consensus?, 24 Marine Policy, 2000, hlm., 1. 
analisis dari keduanya untuk mengetahui substansi pengaturan yang terdapat dalam Konvensi UNESCO 2001, serta keterkaitannya dengan UNCLOS 1982 yang telah lebih dahulu ada dan diratifikasi oleh Indonesia. Selain itu, perlu juga diketahui mengenai masalah kontroversial atau aturan-aturan dan prinsip-prinsip dari Konvensi yang hingga kini masih diperdebatkan, sehingga sulit diterima oleh banyak Negara, termasuk Indonesia.

Sebagai sebuah penelitian doktrinal, penelitian ini akan menyediakan ekspos sistematis terhadap aturan-aturan hukum yang mengatur tentang UCH, menganalisis hubungan antarperaturan, dan menjelaskan ruang hukum yang mengalami hambatan. Hukum internasional utama yang dikaji adalah Konvensi UNESCO 2001 dan UNCLOS 1982. Sedangkan, hukum nasional yang dikaji adalah Undang-undang Nomor 11 tahun 2010 tentang Cagar Budaya (UU Cagar Budaya). Pendekatan interdisipliner diterapkan secara kritis terhadap obyek penelitian, dengan melakukan penjelajahan ilmiah para ilmuwan dalam berbagai disiplin ilmu, terutama pemikir di bidang ilmu hukum dan arkeologi. Analisa berita media turut digunakan dalam metode penggalian data.

\section{Pembahasan}

\section{Substansi Pengaturan dalam Konvensi UNESCO 2001 dan Keterkaitannya dengan UNCLOS 1982}

Konvensi UNESCO 2001 adalah instrumen internasional pertama yang menetapkan prinsip-prinsip dasar bagi pelindungan, perawatan dan penelitian warisan budaya bawah air (UCH) secara eksklusif; serta mempromosikan kerja sama internasional dalam pelestarian dan pelindungannya. ${ }^{17}$ Pelindungan dan pelestarian menjadi konsep inti dari Konvensi UNESCO 2001. Ditujukan bagi semua jejak keberadaan manusia yang memiliki karakter budaya, sejarah, atau arkeologi, yang sekurang-kurangnya telah 100 tahun berada di bawah air secara keseluruhan atau sebagian, berkala atau terus menerus. Definisi dari warisan budaya bawah air ini disebutkan dalam Pasal 1 ayat (1) (a) Konvensi, yakni:

17 Sorna Khakzad, supra no. 15, hlm., 8. 
"[A]ll traces of human existence having a cultural, historical or archaeological character which have been partially or totally under water, periodically or continuously, for at least 100 years.." 18

Definisi tersebut telah mendasari seluruh rezim pelindungan dan pelestarian UCH dengan cakupannya yang luas, dalam dua persyaratan utama, yakni: pertama, berada di dalam air, baik keseluruhan maupun sebagian; kedua, dalam jangka waktu tidak kurang dari 100 tahun. Batasan ini tampaknya tidak berlaku ketat. Meskipun persyaratan batasan 100 tahun harus dihormati oleh Negara-negara pihak, namun mereka dapat berbuat lebih banyak dari yang ditentukan. Beberapa Negara telah melindungi situs-situs terendam yang lebih baru, seperti situs perang dunia abad ke-20 Truk Lagoon di Mikronesia dan Scapa Flow di dekat Skotlandia. ${ }^{19} \mathrm{Hal}$ ini menunjukkan sifat "kontrak" dari Konvensi, di mana Negara pihak dalam memenuhi kewajibannya juga memiliki hak untuk menjamin pelindungan yang lebih baik, melebihi apa yang disyaratkan oleh Konvensi.

Penerapan batas waktu yang tidak ketat dengan melampaui persyaratan minimum 100 tahun, pada akhirnya dianggap sebagai cara terbaik yang dapat dipraktekkan. Hal ini menunjukkan bahwa definisi UCH dengan cakupannya yang luas juga mengandung sifat inklusif dalam definisinya--terbuka atas kemungkinan interpretasi yang lebih dari yang telah ditentukan.

Ciri dasar dari Konvensi UNESCO 2001 adalah menyediakan aturan praktis yang dapat diakui secara luas, berupa teks utama dan lampiran, yang menetapkan aturan-aturan bagi setiap aktivitas yang berkenaan dengan UCH. Tujuannya cukup singkat dan jelas, yakni memastikan dan memperkuat pelindungan $\mathrm{UCH}^{20}$ bagi kemanusiaan (humanity) atau kepentingan umat manusia secara keseluruhan. ${ }^{21}$ Untuk itu, Negara-negara pihak dibebankan kewajiban untuk bekerja sama ${ }^{22}$ dan mengambil semua tindakan yang tepat dan dianggap perlu, sesuai dengan

UNESCO Convention on the Protection of Underwater Cultural Heritage, art. 1 (1) (a).

UNESCO, supra no. 7, hlm., 10.

UNESCO Convention on the Protection of Underwater Cultural Heritage, art. 2 (1).

Id., art. 2 (3).

Id., art. $2(2)$. 
Konvensi dan hukum internasional. Tindakan-tindakan tersebut dilakukan dengan cara-cara terbaik yang dapat dipraktekkan dan yang sesuai dengan kemampuan. ${ }^{23}$

Definisi dengan sifat inklusi yang luas juga tampak pada penyematan frasa "semua jejak keberadaan manusia yang memiliki karakter budaya, sejarah, atau arkeologi."24 Dalam pengertian biasa, definisi ini akan mencakup setiap objek apapun yang terkait dengan campur tangan manusia. ${ }^{25}$ Definisi yang dapat diinterpretasikan begitu luas ini telah menimbulkan perdebatan sejak masa perundingan Konvensi, hingga kini. ${ }^{26}$ Perdebatan yang melampaui diskusi semantik ini seiring dengan masalahnya yang lebih nyata dan kompleks. ${ }^{27}$

Prinsip konservasi tampak kental dalam aturan pengelolaan situs, yakni dengan adanya keharusan penyediaan pelindungan dan pengelolaan in situ. UCH yang dipulihkan harus disimpan, dilestarikan dan dikelola dengan cara yang menjamin pelestarian jangka panjang. ${ }^{28}$ Prinsip pelestarian in situ ini harus menjadi pilihan pertama sebelum diizinkannya aktivitas apapun atas UCH, dengan memastikan bahwa aktivitas yang diarahkan pada UCH telah menggunakan teknik-teknik non-destruktif dan metode survei yang utamanya ditujukan bagi pemulihan objek-objek arkeologi dan bersejarah. ${ }^{29}$ Akses non-intrusif yang bertanggung jawab pun didorong oleh Konvensi untuk mencapai kesadaran publik, apresiasi, dan pelindungan UCH; kecuali akses yang tidak sesuai dengan pelindungan dan pengelolaannya. ${ }^{30}$

Larangan eksploitasi komersial atas UCH diatur oleh Konvensi dengan kewajiban bagi Negara-negara Pihak untuk mengambil langkah-langkah pencegahan masuknya UCH ke wilayah mereka, serta perdagangan dan

Id., art. 2 (4).

Id., art. 1 (1) (a).

Lowell Bautista, supra no. 5, hlm., 13.

26 lihat David J. Bederman, The UNESCO Draft Convention on Underwater Cultural Heritage: A Critique and Counter-Proposal, 30 (2) Journal of Maritime Law and Commerce, 1999, hlm., 331; David J. Bederman, The UNESCO Convention on Underwater Cultural Heritage: Panacea or Peril for Resource Managers? dalam Jennifer R. Richman dan Marion P. Forsyth, Legal Perspectives on Cultural Resources, Altamira Press, United States, 2004, hlm., 143-145.

27 Craig Forrest, Defining Underwater Cultural Heritage, 31 (1) The Journal of Nautical Archeology, 2002, hlm., 3.

28 UNESCO Convention on the Protection of Underwater Cultural Heritage, art. 2 (6).

$29 \quad I d$., art. 2 (5); rule 4 of the Annex.

$30 \quad I d$., art. 2 (10); rule 7 and 8 of the Annex. 
kepemilikannya yang diekspor secara ilegal. ${ }^{31}$ Aturan ke-2 dari Annex Konvensi cukup jelas menyatakan bahwa UCH tidak boleh diperdagangkan, dijual, dibeli, atau dibarter sebagai barang komersial. ${ }^{32}$

Sebagai ketentuan hukum yang mengatur subyek benda atau situs yang sebagian besar berada di lautan, maka tentu saja Konvensi UNESCO 2001 ini terkait erat dengan hukum laut, di mana terkodifikasi dalam Konvensi Perserikatan Bangsa-Bangsa tentang Hukum Laut (United Nations Convention on the Law of the Sea/UNCLOS 1982). Utamanya, adalah terkait dengan konteks siapa atau negara mana yang memiliki otoritas hukum atas warisan budaya tersebut. Terdapat hubungan yang saling melengkapi di antara kedua konvensi tersebut. Keduanya merupakan konvensi dalam sistem Perserikatan Bangsa Bangsa (PBB) sebagai perangkat hukum yang selaras. ${ }^{33}$ UNCLOS 1982 berfokus pada masalah yurisdiksi, sedangkan Konvensi UNESCO 2001 berfokus pada pelindungan warisan budaya.

UNCLOS 1982 memberikan keharusan pemeliharaan dan penggunaan obyek bawah laut untuk kemanfaatan umat manusia sebagai suatu keseluruhan. Senada dengan hal tersebut, Konvensi UNESCO 2001 yang mengedepankan prinsip pelindungan dan penghilangan eksploitasi komersial dari kepemilikan atas kapal karam bersejarah juga mengakui pentingnya UCH sebagai bagian integral dari warisan budaya manusia dan warisan bersama umat manusia.

Klaim atas UCH telah ditentukan dalam konteks zona maritim yang diatur oleh UNCLOS 1982 sebagai kesepakatan internasional yang telah menghasilkan rezim yurisdiksi. UNCLOS 1982 mengakui batas-batas dan zona maritim suatu Negara pantai, serta menyeimbangkan hak-hak Negara pantai dengan hak-hak Negara bendera di setiap zona maritim dengan preferensi yang lebih besar bagi hak Negara pantai di zona terdekat pantainya. Sebagaimana telah disinggung di

\footnotetext{
Id., art. 2 (7); rule 2 of the Annex.

Id., rule 2 of the Annex.

UNESCO Secretariat, the Harmony of the 2001 Convention with UNCLOS, Protection of Culutral Heritage in International Waters, http://www.unesco.org/new/en/culture/themes/underwater-culturalheritage/protection/protection-of-cultural-heritage-in-international-waters/, diakses, 10 November, 2020.
} 
awal tulisan, salah satu alasan utama Negara-negara mendorong aturan hukum internasional dalam rezim Konvensi UNESCO 2001 adalah agar kerjasama antarnegara dan koordinasi pelindungan situs arkeologi bawah air dapat dilakukan di semua zona maritim.

Rezim yurisdiksi yang ditetapkan UNCLOS 1982, terutama yang terkait dengan benda-benda purbakala dan bersejarah, tetap berlaku dalam Konvensi UNESCO 2001. Konvensi UNESCO 2001 menyatakan bahwa Konvensi ini ditafsirkan dan diterapkan dalam konteks dan dengan cara yang konsisten dengan hukum internasional; serta menegaskan bahwa tidak ada sesuatupun dalam Konvensi yang dapat mengurangi hak, yurisdiksi dan kewajiban Negara berdasarkan hukum internasional, termasuk yang telah diatur oleh UNCLOS 1982.34

\section{Persoalan yang Masih Diperdebatkan (contentious issues)}

Pada bagian ini akan dijelaskan beberapa persoalan terkait pengaturan dalam Konvensi yang masih banyak diperdebatkan; yang juga menjadi pertimbangan Indonesia sehingga belum meratifikasi Konvensi UNESCO 2001 sampai saat ini. Persoalan yang dimaksud adalah tentang ketidakjelasan status kepemilikan kapal karam di beberapa zona maritim; kekebalan berdaulat yang melekat pada kapal perang yang tenggelam (sunken warship); dan prinsip pelestarian in situ yang tidak sesuai.

\section{Ketidakjelasan Status Kepemilikan Kapal Karam di Wilayah Laut Kedaulatan}

Baik UNCLOS 1982 maupun Konvensi UNESCO 2001 tidak mengatur dengan jelas perihal kepemilikan kapal yang tenggelam. UNCLOS 1982 berperan dalam memberikan kerangka kerja bagi pelindungan hukum terhadap UCH, yakni melalui Pasal 149 dan Pasal 303. Sementara, Konvensi UNESCO 2001 hanya berfokus pada aspek pelindungan, tanpa secara eksplisit menyatakan hak terkait

34 UNESCO Convention on the Protection of Underwater Cultural Heritage, art. 3. 
kepemilikan. ${ }^{35}$ Kegagalan Konvensi untuk meletakkan dasar-dasar aturan mengenai kepemilikan bangkai kapal itulah yang menyebabkan persoalan masih terus terjadi dan sulit untuk diselesaikan. Potensi konflik yang dapat terjadi adalah antara penemu bangkai kapal beserta benda-benda di dalamnya; Negara asal atau Negara bendera kapal; Negara dari mana muatannya berasal atau Negara asal kebudayaan; maupun Negara pantai di mana kapal tersebut karam.

Meskipun UNCLOS 1982 berlaku untuk seluruh lingkungan laut, namun Pasal 149 hanya menetapkan pelindungan di Area yang berada di luar batas-batas yurisdiksi nasional; ${ }^{36}$ dan Pasal 303 hanya memberi kekuatan pelindungan efektif hingga batas Zona Tambahan (Contiguous Zone). UCH yang berada di wilayah laut dari batas akhir Zona Tambahan hingga batas terluar Zona Ekonomi Eksklusif (ZEE) tidak turut dilindungi oleh UNCLOS 1982.37

Secara umum, pasal 303 mengatur tentang benda-benda purbakala dan benda-benda bersejarah yang ditemukan di laut (archaelogical and historical objects found at sea), ${ }^{38}$ tanpa menjelaskan lebih jauh mengenai pengertian "pemilik" maupun hak-haknya. Meskipun demikian, ayat (2) pasal ini menegaskan tentang benda-benda purbakala dan bersejarah yang diambil tanpa persetujuan Negara pantai yang bersangkutan akan merupakan suatu pelanggaran dalam wilayah atau laut teritorialnya. ${ }^{39}$ Atas ketentuan UNCLOS 1982 tersebut Konvensi UNESCO 2001 menambahkan pengaturan dengan memberi hak bagi Negara

35 Guido Carducci, New Development in the Law of the Sea: The UNESCO Convention on the Protection of Underwater Cultural Heritage, (96) America Society of International Law, 2002, hlm. 420.

36 Pasal 149 UNCLOS 1982 menyebut bahwa semua benda bersifat arkeologi dan bersejarah yang ditemukan di Area harus dilestarikan dan diperuntukkan bagi kepentingan umat manusia secara keseluruhan. Area yang dirujuk oleh Pasal 1 ayat (1) UNCLOS 1982 adalah dasar laut, dasar samudera dan lapisan tanah di bawahnya, yang berada di luar batas-batas yurisdiksi nasional.

37 Negara memiliki hak untuk mengklaim Laut Teritorial tidak melebihi 12 mil laut dari garis pangkal (UNCLOS 1982, art. 3), Zona Tambahan (contiguous zone) yang tidak melebihi 24 mil laut dari garis pangkal (UNCLOS 1982, art. 33) dan ZEE tidak melebihi 200 mil laut dari garis pangkal (UNCLOS 1982, art. 57). Penentuan garis pangkal sesuai dengan Pasal 5-7 UNCLOS 1982.

$38 \quad$ Id., art. 303.

39 Id., art. 303 (2). 
pantai untuk mengatur dan mengesahkan kegiatan yang diarahkan pada UCH di Zona Tambahan. ${ }^{40}$

Dari situ dapat terlihat bahwa meskipun kedua konvensi tidak memberikan status kepemilikan yang jelas atas UCH yang terdapat di wilayah laut kedaulatan, namun muncul syarat sebuah persetujuan dari Negara pantai, agar segala aktivitas terkait benda-benda purbakala dan bersejarah tidak melanggar ketentuan hukum nasional Negara pantai. Sementara dapat ditarik kesimpulan bahwa tanpa status kepemilikan sekalipun, hukum nasional Negara pantai wajib dihormati dan tidak boleh dilanggar.

Hal ini senada dengan prinsip pokok yang muncul dari konvensi UNESCO lainnya, yakni The UNESCO 1970 Convention on the Means of Prohibiting and Preventing the Illicit Import, Export and Transfer of Ownership of Cultural Property (Konvensi UNESCO 1970). Konvensi yang bertujuan untuk menanggulangi perdagangan warisan budaya secara ilegal ini mengakui keberlakuan hukum nasional Negara dalam hal kepemilikan, sebagaimana disebut dalam pasal 13, "The States Parties to this Convention also undertake, consistent with the laws of each State:..."41 Pada situasi di mana konvensi diterapkan secara retroaktif, pembeli benda warisan budaya dapat memperoleh hak kepemilikan setelah memenuhi beberapa persyaratan dan aturan yang berlaku di bawah yurisdiksi negara. ${ }^{42}$

Terkait penyelamat dan penemu kapal yang tenggelam, skema komersial seringkali diterapkan pada UCH dengan merujuk pada hukum penyelamatan (salvage law) dan hukum penemuan (law of finds). Atas costumary international law tersebut Konvensi UNESCO 2001 menegaskan untuk tidak tunduk pada keduanya: "Any activity relating to underwater cultural heritage to which this Convention applies shall not be subject to the law of salvage or law of finds,..."43 Oleh

40 UNESCO Convention on the Protection of Underwater Cultural Heritage, art. 8.

41 UNESCO Convention on the Means of Prohibiting and Preventing the Illicit Import, Export and Transfer of Ownership of Cultural Property, art. 13, November 14, 1970, Treaty Series v.11806 U.N.T.S.

42 Meike Rachmana, The Conception of Historic Shipwrecks Ownership in Accordance with International Law, 12 (3) Jurnal Hukum Internasional, 2015, hlm. 361.

43 UNESCO Convention on the Protection of Underwater Cultural Heritage, art. 4. 
karena itu, menurut Konvensi UNESCO 2001, baik penemu maupun penyelamat UCH tidak akan diakui sebagai pemilik UCH yang dimaksud.

\section{Status Hukum Kapal Perang yang Karam}

Terdapat kontroversi doktrinal pada status hukum kapal perang yang karam (sunken warship) yang hingga kini masih menjadi perdebatan. Ketika sebuah kapal perang yang karam ditemukan, Negara bendera atau tempat kapal itu terdaftar seringkali merujuk pada sebuah rules yang dikenal dengan sovereign immunity. Di dalam UNCLOS 1982, kekebalan berdaulat ini ditujukan bagi kapal Negara, yakni kapal perang atau kapal pemerintah lainnya yang sedang digunakan untuk tujuan non-komersial. ${ }^{44}$ Ketentuan ini hanya mengatur tentang kapal yang masih dapat berlayar dengan normal, namun tidak mengatur perihal status hukum atas kapal perang yang karam.

Beberapa pendapat muncul, di antaranya menyatakan bahwa hak bagi kapal perang yang karam hanya dapat ditinggalkan dengan penolakan secara tegas oleh negara pemilik, dan bahwa penyelamatan/pengamanan (salvage) pada kapal tersebut benar-benar dilarang. ${ }^{45}$ Senada dengan pendapat ini, bahwa kapal perang yang digunakan oleh suatu Negara untuk tujuan non-komersial pada saat tenggelam memiliki status "sovereign wreck".46

Konvensi UNESCO 2001 pun menyebut bahwa kapal laut dan pesawat udara yang dimiliki atau dioperasikan oleh Negara, jika pada saat tenggelam sedang digunakan untuk tujuan non-komersial maka memenuhi definisi sebagai UCH. ${ }^{47}$ Rezim hukum yang baru ini telah melanjutkan status kekebalan penuh atas kapal Negara yang tenggelam. Pasal 1 ayat (8) Konvensi itu lah yang kemudian dipersoalkan, di mana status kedaulatan tetap melekat pada bangkai kapal Negara yang karam.

\footnotetext{
44 United Nations Convention on the Law of the Sea, art. 95 dan 96.

45 David J. Bederman, Rethinking the Legal Status of Sunken Warships, 31 Ocean Development of International Law, 2000, hlm., 97.

46 Craig Forrest, Culturally and Environmentally Sensitive Sunken Warships. 26 Australian and New Zealand Maritime Law Journal, 2012, hlm., 84.

47 UNESCO Convention on the Protection of Underwater Cultural Heritage, art. 1 (8).
} 
Secara khusus, UNCLOS 1982 sendiri telah memberikan definisi dari kapal perang, yakni kapal yang dimiliki oleh angkatan bersenjata sebuah Negara di bawah komando seorang perwira yang diangkat oleh Pemerintah Negaranya, dan diawaki oleh awak kapal yang tunduk pada disiplin militer. ${ }^{48}$ Pasal 29 UNCLOS 1982 ini memberikan batasan dengan jelas bahwa kapal perang hanya menjadi organ Negara selama mereka diawaki oleh awak kapal yang dipimpin oleh seorang perwira di bawah disiplin militer, serta berlayar dalam tugas pelayanan Negara.

Oleh karena itu, patut diartikan bahwa kapal perang yang karam tidak lagi menyandang hak berdaulat (sovereign immunity) dari Negara bendera. Secara logis, alasannya adalah karena kapal yang karam itu sudah tidak mungkin beroperasi di bawah komando seorang perwira maupun memiliki awak kapal lagi, baik karena ditinggalkan atau karena tenggelam bersama awaknya. Sederhananya, kapal perang yang karam dan telah ditinggalkan oleh krunya tidak bisa lagi menjadi organ Negara, sehingga tidak menyandang hak berdaulat.

\section{Penerapan Prinsip Pelestarian In Situ yang Kurang Tepat}

Frasa in situ dipahami sebagai istilah yang merujuk pada pelestarian benda atau situs arkeologi di tempat atau lokasi aslinya alih-alih dipindahkan ke tempat lain, ${ }^{49}$ dan biasanya berarti pelestarian tanpa gangguan. Hal ini menjadi sulit jika memperhatikan aktivitas berbagai kepentingan yang ada. Bahkan, bagi kelompok ilmuwan (arkeolog) sekalipun akan sulit mempertahankan keadaan alami dari situs karena kegiatan kunjungan dalam penelitian (research impact).

Dalam dokumen "The Benefit of the Protection of Underwater Cultural Heritage for Sustainable Growth, Tourism and Urban Development",50 UNESCO bersama Badan Penasihat Ilmiah dan Teknis Konvensi UNESCO 2001 telah mempromosikan wisata selam dan kapal pesiar sebagai salah satu manfaat yang dapat diambil dari UCH. Dokumen promosi ini menyampaikan bahwa 37\% dari

48 United Nations Convention on the Law of the Sea, art. 29.

49 Cambridge Dictionary, "in situ", https://dictionary.cambridge.org/dictionary/english/in-situ; lihat juga Merriam-Webster, https://www.merriam-webster.com/dictionary/in\%20situ.

50 UNESCO Secretariat dan the Scientific and Technical Advisory Body of the Convention on the Protection of the Underwater Cultural Heritage, The Benefit of the Protection of Underwater Cultural Heritage for Sustainable Growth, Tourism and Urban Development, 2001. 
pariwisata global memiliki motivasi budaya, sehingga keterkaitan antara budaya dan pariwisata tidak dapat dihindari. ${ }^{51}$ Promosi ini tentu saja menjadi bentuk ketidakkonsistenan prinsip pelestarian in situ yang dibuat oleh UNESCO sendiri, jika in situ merujuk pada pelestarian "tanpa gangguan".

Pelindungan tidak lah identik dengan menjaga agar tidak dapat dilihat atau disentuh. ${ }^{52}$ Kemampuan model ini dalam melestarikan situs pun belum terbukti dan masih memerlukan penyelidikan lebih lanjut. Akhirnya, pelestarian in situ diibaratkan sebagai "cara menyaksikan pembusukan benda purbakala melalui program pemantauan yang mahal."53

Pelestarian in situ hanyalah salah satu alat yang tersedia bagi arkeolog, konservator, dan pengelola sumber daya budaya, terutama menjadi solusi pragmatis untuk menstabilkan situs atau penyimpanan jangka panjang saat sumber daya tidak tersedia bagi konservasi dan kurasi. ${ }^{54}$ Maka, definisi in situ harus diformulasikan dengan gambaran model yang lebih jelas, agar menghilangkan ambiguitas pengertian yang berdampak pada model pengelolaan situs yang salah atau dianggap bertentangan.

\section{Kebijakan Indonesia dalam Pengelolaan Warisan Budaya Bawah Air Asas Kemanfaatan}

Politik hukum Indonesia terkait peninggalan purbakala dan sejarah telah mendorong pengelolaan warisan budaya agar dipergunakan bagi kesejahteraan seluruh rakyat Indonesia. ${ }^{55}$ Asas kemanfaatan yang diusung oleh Undang-undang Republik Indonesia Nomor 11 Tahun 2010 tentang Cagar Budaya (UU Cagar

$51 \quad$ Id, hlm., 6.

52 Randal James Sasaki, The History, Present, and Future of Underwater Cultural Heritage Management in Japan, Disertasi Texas A\&M University, 2019, hlm. 115.

53 Bulletin of The Maritime Affairs Group, Institute of Field Archaeologists, Winter 2008, sebagaimana dikutip oleh David Gregory, In Situ Preservation of Marine Archaeological Sites: Out of Sight but Not Out of Mind, dalam Vicki Richards and Jennifer McKinnon (eds.), In Situ Conservation of Cultural Heritage: Public, Professionals and Preservation, Flinders University Program in Maritime Archaeology, Victoria, 2009, hlm., 1.

54 David Gregory, In Situ Preservation of Marine Archaeological Sites: Out of Sight but Not Out of Mind, dalam Vicki Richards and Jennifer McKinnon (eds.), In Situ Conservation of Cultural Heritage: Public, Professionals and Preservation, Flinders University Program in Maritime Archaeology, Victoria, 2009, hlm., 1-2. 
Budaya) dimaksudkan untuk pengembangan dan pelestarian cagar budaya bagi kepentingan rakyat. ${ }^{56}$ Undang-undang ini melihat bahwa dalam upaya pelestarian warisan budaya, Negara bertanggung jawab dalam hal pengaturan, pelindungan, pengembangan, dan pemanfaatan. ${ }^{57}$ Di samping itu, perubahan paradigma pelestarian memerlukan keseimbangan antara aspek ideologis, akademis, ekologis, dan ekonomis untuk meningkatkan kesejahteraan rakyat. ${ }^{58}$

Para ilmuwan arkeologi dan sejarah mengakui bahwa manusia merupakan faktor penting dalam pelestarian peninggalan bawah laut, bukan semata-mata kapal, kargo, peralatan dan perlengkapan yang ditemukan. ${ }^{59}$ Arkeologi maritim tidak sekedar mempelajari aspek teknologi belaka, melainkan kebudayaan maritim yang lebih luas yang mengandung aspek sosial, ekonomi, politik, agama, dan yang lainnya. Hingga akhirnya, pemanfaatan benda-benda arkeologi ini harus berguna bagi masyarakat.

Disiplin ilmu sosial budaya yang diarahkan pada manajemen pengelolaan UCH telah diakui secara internasional. Pengelolaannya mengarah pada tiga aspek utama, yakni: penelitian, pelindungan, serta interpretasi dan akses publik. Baik pelindungan maupun pemanfaatan yang dilakukan terhadap UCH harus konsisten dalam meningkatkan pembangunan sosial budaya dan pertumbuhan ekonomi masyarakat lokal. 60

Konsep kemitraan yang melibatkan banyak kepentingan menjadi contoh keberhasilan manajemen, yang tidak dapat bekerja secara efektif tanpa minat lokal pada nilai-nilai historis dan tujuan keberlangsungan industri (wisata) jangka panjang. ${ }^{61}$ Kemitraan tersebut mencakup industri wisata alam lokal, lembaga atau kelompok masyarakat lokal, kelompok kepentingan lokal lainnya, serta

56 Id., Pasal 2 (f) dan 78 (1).

57 Undang-undang R.I., No. 11 Tahun 2010, Cagar Budaya, L.N.R.I. Tahun 2010 No. 130, bagian Menimbang huruf (b).

58 Id., bagian Menimbang huruf (d).

59 lihat Keith Muckelroy, Maritime Archaelogy, Cambridge, London, 1978.

60 Massimiliano Secci \& Pier Giorgio Spanu, Critique of Practical Archaelogy: Underwater Cultural Heritage and Best Practices, $10 \mathrm{~J}$ Mari Arch., 2015, hlm., 29-30.

61 David Nutley, Protected Zones and Partnerships: Their Application and Importance to Underwater Cultural Heritage Management, dalam ICOMOS (ed.), Heritage at Risk Special Edition, 2006, hlm., 34. 
pemerintah daerah. Untuk itu, pengelolaan situs yang efektif berarti memberikan pelindungan kepada warisan budaya sekaligus pengalaman berkualitas pada pengunjung situs. Dampak jangka panjangnya adalah manfaat bagi industri pariwisata serta masyarakat lokal yang secara finansial bergantung pada situssitus tersebut, dengan manfaat tambahan bagi ekonomi lokal dan regional. ${ }^{62}$

Contoh pengelolaan situs kapal karam tanpa menerapkan prinsip in situ yang telah dikembangkan di Indonesia adalah pengelolaan situs kapal karam United States Army Transport (USAT) Liberty di Desa Tulamben, Bali. Dikembangkan sebagai obyek wisata berbasis kearifan lokal dengan konsep kemitraan.63 Penelitian tentang "kualitas ketertarikan fisik dan kenyamanan wisatawan" telah dilakukan atas situs USAT Liberty untuk mengetahui kemampuan daya dukung fisik situs. ${ }^{64}$ Penelitian tersebut menyimpulkan keberhasilan pengelolaan situs dengan prinsip-prinsip konservasi, meskipun tanpa menerapkan pelestarian in situ.

Terkait prinsip eksploitasi non-komersial yang diusung Konvensi UNESCO 2001, Keputusan Presiden tentang Panitia Nasional Pengangkatan dan Pemanfaatan Benda Berharga Asal Muatan Kapal yang Tenggelam (BMKT) memberikan pertimbangan bahwa sejarah, budaya, ilmu pengetahuan dan ekonomi merupakan sumber daya kekayaan laut yang pemanfaatannya perlu dikelola untuk peningkatan kesejahteraan rakyat dan pembangunan nasional. ${ }^{65}$ Pada prinsipnya, BMKT merupakan benda yang dikuasai Negara dan dikelola oleh Pemerintah. ${ }^{66}$ Atas BMKT yang tidak dinyatakan sebagai milik negara akan

62 Joanne Edney, A Framework for Managing Diver Impacts on Historic Shipwrecks. 11 (3) Journal of Maritime Archaeology, 2016, hlm., 271-297.

63 Gde Yadnya Tenaya, Pengelolaan Cagar Budaya Berbasis Kearifan Lokal (2017), Dirjen Kebudayaan Kementerian Pendidikan dan Kebudayaan,

https://kebudayaan.kemdikbud.go.id/ditpcbm/pengelolaan-situs-kapal-usat-liberty-berbasiskearifan-lokal/, diakses 19 April 2020.

64 Mohamad Febrian Gamma Rizaldy dan Ida Bagus Suryawan, Studi Daya Dukung Fisik Wisata Bahari Usat Liberty Wreck di Desa Tulamben Bali, 7 (1) Jurnal Destinasi Pariwisata, 2019, hlm., 166.

65 Keputusan Presiden R.I., No. 19 Tahun 2007, Panitia Nasional Pengangkatan dan Pemanfaatan Benda Berharga Asal Muatan Kapal yang Tenggelam, bagian Menimbang (a).

66 Keputusan Presiden R.I., No. 12 Tahun 2009, Panitia Nasional Pengangkatan dan Pemanfaatan Benda Berharga Asal Muatan Kapal yang Tenggelam, Pasal 2. 
dimanfaatkan sesuai dengan ketentuan peraturan perundang-undangan. ${ }^{67}$ Saat ini, terdapat Galeri BMKT Kementerian Kelautan, tempat dipamerkannya temuantemuan dari beberapa lokasi BMKT di perairan Indonesia. Di antaranya, berasal dari Kargo Belitung, Kargo Cirebon, dan Kargo Pulau Buaya. ${ }^{68}$

Kebijakan nasional terbaru pun membuka kembali peluang pengangkatan BMKT dari dasar laut. Melalui Peraturan Presiden Nomor 10 Tahun 2021 tentang Bidang Usaha Penanaman Modal, pemerintah menetapkan bidang usaha pengangkatan BMKT yang terbuka untuk investasi asing. Perpres ini merupakan aturan pelaksana dari Undang-Undang Nomor 11 Tahun 2020 tentang Cipta Kerja, sesuai Pasal 77 dan 185 huruf b.

Opsi pengangkatan BMKT ini dipilih oleh pemerintah mengingat banyaknya kapal karam bermuatan benda berharga yang berlokasi di perairan dangkal. Lokasi-lokasi tersebut relatif mudah dicapai sehingga berpotensi pada perusakan dan pencurian. Alih kebijakan terhadap BMKT yang mengubah pengelolaan menjadi pengangkatan sesungguhnya didorong oleh nilai BMKT itu sendiri yang begitu kompleks. Selain mendukung kajian arkeologi, sejarah dan perkembangan ilmu pengetahuan lainnya, BMKT juga memiliki nilai ekonomi yang tinggi. Data Penelitian dan Pengembangan Kementerian Kelautan dan Perikanan Republik Indonesia (KKP) tahun 2000 menyebutkan bahwa terdapat 463 titik lokasi BMKT. Hingga tahun 2018 telah dilakukan 20\% verifikasi dan 3\% dieksplorasi. Dari setiap lokasi, KKP menaksir nilai ekonomi sebesar US\$ 80.000 hingga US\$ delapan belas juta. ${ }^{69}$

\section{Kebijakan Indonesia atas Kapal Negara yang Karam}

Klaim atas UCH tidak hanya terjadi di laut bebas di mana tidak ada yurisdiksi Negara atas perairan tersebut. Persoalan semakin rumit saat lokasi

\footnotetext{
67 Id., Pasal 4 (2).

68 DJKN Kementerian Keuangan RI, Sebanyak Apa Harta Karun yang Ada di Perairan Indonesia Sekarang? (Februari, 2017), Kemenkeu RI, https://www.djkn.kemenkeu.go.id/2013/beritamedia/sebanyak-apa-harta-karun-adaperairan-indonesia-sekarang, diakses 9 April 2020.

69 Kementerian Kelautan dan Perikanan Republik Indonesia, FAQ Barang Muatan Kapal Tenggelam (BMKT) (Maret, 2018), KKP RI, https://kkp.go.id/artikel/2639-faq-barangmuatan-kapal-tenggelam-bmkt, diakses 9 April 2020.
} 
bangkai kapal Negara berada di Laut Teritorial Negara lain. Terkait status kepemilikannya, UU Cagar Budaya dengan jelas menyatakan bahwa UCH yang disebut sebagai Cagar Budaya tersebut dikuasai oleh Negara, kecuali telah terjadi pengalihan hak yang mekanismenya diatur oleh undang-undang. ${ }^{70}$

Hingga kini tercatat 46 titik kerangka kapal perang asing yang berada di Perairan Indonesia. ${ }^{71}$ Beberapa kasus terkait kapal perang yang karam, baik di wilayah Perairan Indonesia maupun wilayah Yurisdiksi Indonesia sempat muncul. Penyelesaian dan sikap resmi yang diambil menjadi gambaran sikap politik hukum Indonesia atas kapal perang asing tersebut dan kebijakan nasional secara umum yang diterapkan atas UCH.

Dalam Rapat Koordinasi Tindak Lanjut Pengelolaan Benda Berharga Asal Muatan Kapal Yang Tenggelam (BMKT) yang dilakukan secara daring pada 1 April 2020, Kementerian Kelautan dan Perikanan Republik Indonesia (KKP) menjelaskan kembali inisiasi penetapan Kawasan Konservasi Maritim atas kerangka kapal perang asing yang berada di Teluk Banten. Dalam pertemuan tersebut ditekankan kembali pula perihal lokasi BMKT yang dapat dikelola sebagai kawasan lindung guna mendukung atraksi wisata selam. Sedangkan bagi BMKT yang dapat diangkat, mekanismenya akan mengikuti ketentuan dalam perizinan lokasi dan perizinan pengelolaan. ${ }^{72}$

Dalam beberapa kasus, diplomasi maritim antarnegara dilakukan untuk menghindari ketegangan yang muncul. Pada akhir tahun 2013, HMAS Perth yang tenggelam oleh Jepang pada tahun 1942 telah dihancurkan oleh commercial salvagers. ${ }^{73}$ Situs kapal perang HMAS Perth yang tenggelam dalam Perang Dunia II di Selat Sunda itu akhirnya dijadikan Kawasan Konservasi Maritim oleh

70 Undang-undang R.I., No. 11 Tahun 2010, Cagar Budaya, L.N.R.I. Tahun 2010 No. 130, Pasal 1 (9); 12 (3); 13.

71 Kementerian Kelautan dan Perikanan, Koordinasi Tindak Lanjut Pengelolaan Benda Muatan Kapal Tenggelam (BMKT) (April, 2020), DJPRL KKP RI, https://kkp.go.id/djprl/jaskel/artikel/18385-koordinasi-tindak-lanjut-pengelolaan-bendamuatan-kapal-tenggelam-bmkt, diakses 17 April 2020.

72 Id.

73 Natali Pearson, Finders, not keepers (Maret 2016), insideindonesia.org, https://www.insideindonesia.org/finders-not-keepers, diakses 10 November 2020. 
Indonesia. ${ }^{74}$ Dalam diplomasi ini, dengan didampingi pejabat KKP, Pemerintah Daerah Provinsi Banten, dan TNI AL; utusan pemerintah dan militer Amerika Serikat dan Australia dapat menggelar upacara mengenang dan menghormati kapal perang dan sejumlah marinir mereka yang tewas dan hilang di perairan Selat Sunda. ${ }^{75}$

Di lain kasus pada tahun 2017, keluarga pelaut Belanda dikejutkan atas hilangnya kapal perang HNLMS Java dan HNLMS De Ruyter yang karam di dekat Pulau Bawean pada tahun 1942. Kapal ini pun hilang diambil oleh para pemburu kapal karam. ${ }^{76}$ Atas kasus ini, Indonesia menolak tuduhan telah lalai menjaga bangkai kapal perang. Angkatan Laut Tentara Nasional Indonesia (TNI AL) memberikan pernyataan resmi melalui juru bicaranya bahwa bangkai kapal-kapal perang milik Belanda dan Inggris yang tenggelam di perairan Indonesia itu sudah selayaknya tidak diganggu. Namun, TNI AL pun menyatakan bahwa bukan tanggung jawab Indonesia untuk melindungi kapal-kapal karam tersebut, terutama karena luasnya wilayah Perairan Indonesia yang tidak memungkinkan untuk dipantau sepanjang waktu. ${ }^{77}$ Senada dengan hal ini, Kepala Pusat Arkeologi Nasional di Kementerian Pendidikan dan Kebudayaan menyatakan bahwa kejadian tersebut bukan menjadi tanggung jawab Indonesia; Indonesia tidak dapat disalahkan karena tidak pernah ada permintaan resmi dari Negara-negara yang merasa dirugikan itu untuk melindungi kapal-kapalnya. ${ }^{78}$

\section{Kedaulatan Negara dan Pilihan Rasional}

Tidak ada Negara yang dapat memaksakan yurisdiksi atas Negara lain. Sebagai anggota masyarakat internasional, pada prinsipnya setiap Negara adalah

74 Keputusan Menteri Kelautan dan Perikanan R.I., No. 21/KEPMEN-KP/2018, Kawasan Konservasi Maritim HMAS Perth di Perairan Provinsi Banten.

75 Maria Rita Hasugian, 24 Kapal Perang Asing Karam di Perairan Indonesia (2 Maret 2019), tempo.co, https://dunia.tempo.co/read/1181105/24-kapal-perang-asing-karam-di-perairanindonesia, diakses 18 April 2020.

76 Linton Besser, HMAS Perth: WWII warship grave stripped by salvagers (Desember, 2013), abc.net.au, https://www.abc.net.au/news/2013-12-13/outrage-as-warship-grave-strippedby-salvagers/5156320, diakses 17 April 2020.

77 hp (afp,dpa), Indonesia Tolak Tuduhan Lalai Atas Bangkai Kapal Perang (November, 2016), dw.com, https://p.dw.com/p/2StAY, diakses 10 November 2020.

78 Natali Pearson, supra no 65. 
sama atau memiliki kedudukan yang setara. Indonesia sebagai negara berdaulat memiliki hak untuk mengatur dirinya sendiri secara independen dari kekuatan asing, apapun bentuk konstitusi internalnya. ${ }^{79}$ Dalam hubungan internasional sendiri tidak terdapat agen sentral dengan otoritas yang dapat memaksa berlakunya hukum internasional.80 Meskipun sistem penghargaan dan sanksi dapat diterapkan, namun hukum internasional lebih memiliki dasar kekuatan mengikat dari adanya kepentingan dan kebutuhan untuk terjadinya ketertiban dan kepastian hukum dalam melaksanakan hubungan tersebut. ${ }^{81}$

Dalam konsep decission making approach, pilihan rasional setiap keputusan akan berusaha memaksimalkan value yang didapat dengan mempertimbangkan antara cost yang harus dikeluarkan dan benefit yang akan didapatkan. Tujuan utamanya adalah untuk mencapai keamanan dan kepentingan nasional. ${ }^{82}$ Uniknya, dua Negara dengan kepentingan nasional yang berbeda, bahkan bertolak belakang, berujung pada keputusan yang sama, yakni dalam hal ini menolak ratifikasi Konvensi UNESCO 2001. Sebagai contoh, Inggris mengkritik kemungkinan meluasnya yurisdiksi Negara pantai (dikenal pula dengan istilah 'creeping coastal State jurisdiction'] yang dapat mengganggu keseimbangan yurisdiksi yang telah dicapai dalam UNCLOS 1982. Bersama itu pula Inggris menganggap telah terjadi pengikisan prinsip sovereign immunity yang diterapkan pada kapal perang dan kapal Negara lainnya.83

Sebaliknya, bagi Indonesia, kedaulatan yang melekat pada sunken warship merupakan persoalan bagi kedaulatan nasional. Banyaknya kapal perang dan kapal Negara asing yang tenggelam di wilayah Perairan Indonesia dapat

79 Henry Wheaton, Elements of International Law: with a Sketch of the History of the Science. Carey, Lea \& Blanchard Philadephia, 1836. hlm., 51.

80 Markus Burgstaller, Theories of Compliance with International Law: Development in International Law, Vol. 52, Martinus Nijhoff Publishers and VSP, 2005, hlm., 85.

81 Andrew T. Guzman, How International Law Works a Rational Choice Theory, Oxford University Press, New York, 2008, hlm., 20-21.

82 Graham T. Allison, Conceptual Models and the Cuban Missile Crisis, Vol. 63 (3), The American Political Science Review, 1969, hlm., 694.

83 Michael V. Williams, UNESCO Convention on the Protection of the Underwater Cultural Heritage: An Analysis of the United Kingdom's Standpoint, proceedings of the Burlington House Seminar October 2005, published for the Joint Nautical Archaelogy Policy Committee, The Natutical Archaeology Society, 2006, hlm., 3. 
menimbulkan persoalan. Jika sunken warship itu karam di Laut Teritorial, itu sama dengan terdapat hak berdaulat Negara asing di wilayah kedaulatan Indonesia. Indonesia akan menemui kesulitan dalam pengawasan kapal-kapal karam di seluruh perairan Indonesia yang begitu luas. Indonesia pun akan dirugikan jika hanya dituntut untuk mengawasi namun tidak diizinkan mengeksploitasi secara komersial.

Pada akhirnya, Indonesia tidak memiliki kewajiban untuk meratifikasi sebuah konvensi, pun tidak ada sanksi yang dapat dijatuhkan oleh masyarakat internasional jika tidak meratifikasi Konvensi UNESCO 2001. Ratifikasi didefinisikan sebagai tindakan internasional di mana suatu negara menunjukkan persetujuannya untuk terikat pada suatu perjanjian. ${ }^{84} \mathrm{Di}$ bawah hukum internasional, tidak ada kewajiban umum yang dibebankan pada suatu Negara untuk meratifikasi sebuah perjanjian. Ratifikasi merupakan pernyataan dari kebijakan Negara, yang dapat tidak dilakukan sampai kapanpun dan untuk alasan apapun. Bahkan, tidak ada alasan yang perlu diberikan dalam hal menolak meratifikasi sebuah perjanjian. ${ }^{85} \mathrm{Hal}$ ini terkait dengan prinsip kedaulatan negara dan kebebasan yang dimiliki olehnya untuk terikat ataupun tidak terikat dengan hukum internasional.

\section{Penutup}

UU Cagar Budaya adalah salah satu bukti yang menunjukkan komitmen Indonesia dalam upaya pelindungan warisan budaya bawah air. Paradigma pelestarian dalam UU Cagar Budaya yang mengarah pada keseimbangan aspek ideologis, akademis, ekologis, dan ekonomis bagi peningkatan kesejahteraan rakyat telah memberi dasar pengertian pelindungan UCH yang ditujukan bagi semua pemangku kepentingan nasional. Meskipun aturan nasional masih memberikan peluang bagi pengangkatan BMKT, namun hal tersebut dilaksanakan dengan mengindahkan prinsip konservasi dan kehati-hatian. Kebijakan ini harus

84 Vienna Convention on the Law of Treaties 1969, art. 2 (1) (b), Mei 23, 1969, 1155 U.N.T.S. 331, 8 I.L.M.

85 John Mervyn Jones, Full Powers and Ratification: A Study in the Development of Treaty-making Procedure, Cambridge University Press, Cambridge, 1949, hlm., 79. 
dilihat sebagai upaya Negara untuk mengambil semua tindakan yang tepat dan dianggap perlu, sesuai kemampuannya, dalam melindungi UCH di wilayah lautnya yang sangat luas dari tindakan-tindakan yang berujung pada perusakan dan perdagangan secara ilegal. Model pengelolaan UCH yang dibangun sebagai kawasan konservasi maritim maupun obyek kunjungan wisata selam, merupakan pilihan logis yang secara efektif dapat memberikan nilai tambah secara ekonomi, pengalaman berkualitas bagi banyak pihak, sekaligus peningkatan kesadaran masyarakat luas akan nilai dan arti penting melindungi sumber daya budaya dan bersejarah yang dimiliki.

Keengganan Indonesia untuk meratifikasi Konvensi UNESCO 2001 yang juga dialami oleh banyak negara lainnya disebabkan oleh beberapa faktor, seperti: adanya persoalan politik hukum yang rumit; ketidakpastian status kepemilikan warisan budaya bawah air; prinsip sovereign immunity dari kapal Negara yang karam; serta beberapa definisi dan aturan di dalam Konvensi UNESCO 2001 yang hingga kini masih banyak diperdebatkan. Contentious issues yang masih bertahan tersebut dan perbedaan paradigma pelestarian yang dianut menunjukkan bahwa Konvensi UNESCO 2001 belum memadai maupun memberi manfaat bagi Indonesia dalam upaya pelindungan dan pemanfaatan warisan budaya bawah air di wilayah Perairan Indonesia. Oleh karena itu, tulisan ini pun sampai pada pendapat bahwa Indonesia tidak perlu tergesa-gesa dalam menentukan sikap untuk meratifikasi Konvensi UNESCO 2001, hingga benar-benar yakin bahwa Konvensi tersebut telah memadai dan dapat memberi manfaat bagi Indonesia. 


\section{Daftar Pustaka}

\section{Buku:}

Andrew T. Guzman, How International Law Works a Rational Choice Theory, Oxford University Press, New York, 2008.

Anastasia Strati, The Protection of the Underwater Cultural Heritage: An Emerging Objective of the Contemporary Law of the Sea, Kluwer Law International, Netherlands, 1995.

Geoff Bailey, Nena Galanidou, Hans Peeters, Hauke Jöns, Moritz Mennenga (eds.), The Archaelogy of Europe's Drowned Landscapes, Coastal Research Library, Volume 35, USA, 2020.

Jennifer R. Richman and Marion P. Forsyth, Legal Perspectives on Cultural Resources Altamira Press, United States, 2004.

John Carman, Archaeology and Heritage: An Introduction, Continuum, New York, 2001.

John Mervyn Jones, Full Powers and Ratification: A Study in the Development of Treaty-making Procedure, Cambridge University Press, UK, 1949.

Keith Muckelroy, Maritime Archaeology, Cambridge University Press, London, 1978.

National Association of Underwater Instructors, NAUI Leadership and Instruction, NAUI, third edition, USA, 2009.

Sarah Dromgoole, Underwater Cultural Heritage and International Law. Cambridge University Press, UK, 2014.

Vicki Richards and Jennifer McKinnon (eds.), In Situ Conservation of Cultural Heritage: Public, Professionals and Preservation, Flinders University Program in Maritime Archaeology, Victoria, 2009.

Jurnal/Makalah/Artikel/Prosiding:

Craig Forrest, Defining Underwater Cultural Heritage, 31 (1) The Journal of Nautical Archeology, 2002

Culturally and Environmentally Sensitive Sunken Warships. 26 Australian and New Zealand Maritime Law Journal, 2012.

David J. Bederman, The UNESCO Draft Convention on Underwater Cultural Heritage: A Critique and Counter-Proposal, 30 (2) Journal of Maritime Law and Commerce, 1999.

Rethinking the Legal Status of Sunken Warships, 31 Ocean Development of International Law, 2000.

David Nutley, Protected Zones and Partnerships: Their Application and Importance to Underwater Cultural Heritage Management. Heritage at Risk Special Edition edited by ICOMOS, 2006.

Geoff Bailey, The Significance of Underwater Cultural Heritage, Makalah disajikan dalam Kolokium Ilmiah UNESCO tentang Faktor-Faktor yang Mempengaruhi Warisan Budaya Bawah Air, Brussel: Royal Library of Belgium, 2011.

Graham T. Allison, Conceptual Models and the Cuban Missile Crisis, 63 (3) The American Political Science Review, 1969. 
Joanne Edney, A Framework for Managing Diver Impacts on Historic Shipwrecks, 11 Journal of Maritime Archaeology, 2016.

Lowell Bautista, Ensuring the Preservation of Submerged Treasures for the Next Generation: The Protection of Underwater Cultural Heritage in International Law, prosiding LOSI Conference Papers "Securing the Ocean for the Next Generation", Seoul, Korea, Mei, 2012.

Massimiliano Secci \& Pier Giorgio Spanu, Critique of Practical Archaelogy: Underwater Cultural Heritage and Best Practices, $10 \mathrm{~J}$ Mari Arch, 2015.

Michael V. Williams, UNESCO Convention on the Protection of the Underwater Cultural Heritage: An Analysis of the United Kingdom's Standpoint, proceedings of the Burlington House Seminar October 2005, published for the Joint Nautical Archaelogy Policy Committee, The Natutical Archaeology Society, 2006.

Mohamad Febrian Gamma Rizaldy dan Ida Bagus Suryawan, Studi Daya Dukung Fisik Wisata Bahari Usat Liberty Wreck di Desa Tulamben Bali, 7 (1) Jurnal Destinasi Pariwisata. 2019.

Paul Fletcher-Tomenius and Craig Forrest, Historic Wreck in International Waters: Conflict or Consensus? 24 Marine Policy 24, 2000.

Sorna Khakzad, Underwater Cultural Heritage Sites on the Way to World Heritage: To Ratify the 2001 Convention or not to Ratify? 2 (1) Journal of Anthropology and Archaeology, 2014.

Ulrike Guérin, What benefits can States derive from ratifying the UNESCO Convention on the Protection of the Underwater Cultural Heritage 2001? Draft Frequently Asked Questions: UNESCO internal material, 2001.

UNESCO dan the Scientific and Technical Advisory Body of the Convention on the Protection of the Underwater Cultural Heritage 2001. The Benefit of the Protection of Underwater Cultural Heritage for Sustainable Growth, Tourism and Urban Development, 2001.

\section{Internet:}

Direktorat Jenderal Kekayaan Negara Kementerian Keuangan RI, Sebanyak Apa Harta Karun yang Ada di Perairan Indonesia Sekarang? (2013), DJKN Kemenkeu RI, https://www.djkn.kemenkeu.go.id/2013/beritamedia/ sebanyak-apa-harta-karun-ada-perairan-indonesia-sekarang, diakses 9 April 2020.

Kate Lamb, UK in talks with Indonesia over missing sunken WWII warships (Maret, 2018), the Guardian International edition, https://www.theguardian.com/ world/2018/mar/07/uk-in-talks-with-indonesia-over-missing-sunkenwwii-warships, diakses 17 April 2020.

Kementerian Kelautan dan Perikanan, Koordinasi Tindak Lanjut Pengelolaan Benda Muatan Kapal Tenggelam (BMKT) (April, 2020), DJPRL KKP RI, https://kkp.go.id/djprl/jaskel/artikel/18385-koordinasi-tindak-lanjutpengelolaan-benda-muatan-kapal-tenggelam-bmkt, diakses 17 April 2020.

Linton Besser, HMAS Perth: WWII warship grave stripped by salvagers (Desember, 2013),

Australian

Broadcasting

Association, 
https://www.abc.net.au/news/ 2013-12-13/outrage-as-warship-gravestripped-by-salvagers/5156320, diakses 17 April 2020.

Maria Rita Hasugian, 24 Kapal Perang Asing Karam di Perairan Indonesia (Maret, 2019), Tempo.co, https://dunia.tempo.co/read/1181105/24-kapalperang-asing-karam-di-perairan-indonesia, diakses 18 April 2020.

Markus Burgstaller, Theories of Compliance with International Law: Development in International Law, Vol. 52, Martinus Nijhoff Publishers and VSP, 2005.

Natali Pearson, Finders, not keepers (Maret 2016), insideindonesia.org, https://www.insideindonesia.org/finders-not-keepers, diakses 10 November 2020.

R. Patrick Jones, Jacques Cousteau and the History of Scuba Diving (Maret, 2017), Deepblu,https://www.deepblu.com/post/81641b20107c11e7aa9ad181bc 785596, diakses 17 April 2020.

UNESCO, Daftar Negara peratifikasi Konvensi UNESCO 2001 hingga 15 November 2019,http://www.unesco.org/eri/la/convention.asp?KO=13520\&language =E\&order=alpha, diakses 16 April, 2020.

\section{Perundangundangan dan Konvensi:}

Keputusan Presiden Republik Indonesia Nomor 19 Tahun 2007, 19 September 2007, tentang Panitia Nasional Pengangkatan dan Pemanfaatan Benda Berharga Asal Muatan Kapal yang Tenggelam.

Nomor 12 Tahun 2009, 22 April 2009, tentang Perubahan atas Keputusan Presiden Nomor 19 tahun 2007 tentang Panitia Nasional Pengangkatan dan Pemanfaatan Benda Berharga Asal Muatan Kapal yang Tenggelam.

Keputusan Menteri Kelautan dan Perikanan R.I., No. 21/KEPMEN-KP/2018, tentang Kawasan Konservasi Maritim HMAS Perth di Perairan Provinsi Banten.

Undang-Undang Nomor 11 Tahun 2010, 24 November 2010, LNRI Tahun 2010 Nomor 5168 Tentang Cagar Budaya.

United Nations Convention on the Law of the Sea (adopted 10 December 1982, entered into force 16 November 1994), 1833 UNTS 396.

Convention on the Protection of the Underwater Cultural Heritage (adopted 2 November 2001, entered into force 2 January 2009), UNESCO Doc 31C/Res 24; (2002) 41 ILM 37. 